\title{
Trophic ecology of dominant zooplankton and macrofauna in a temperate, oligotrophic South African estuary: a fatty acid approach
}

\author{
Nicole B. Richoux* ${ }^{*}$ P. William Froneman \\ Department of Zoology and Entomology, PO Box 94, Rhodes University, Grahamstown, 6140 South Africa
}

\begin{abstract}
Fatty acid profiles of food sources, dominant zooplankton, macrofauna and a few small ichthyofauna in a temperate estuary on the southeastern coast of South Africa were used to trace the original carbon sources and the degree of feeding plasticity of consumers within an oligotrophic environment. Fatty acid analysis is seldom used to examine food web ecology in estuaries, as these systems are typically highly complex owing to the variety of potential food sources and the variable nature of detritus. We hypothesized that generalist consumers would exhibit similar and overlapping fatty acid compositions, whereas any specialist consumers would 'stand out' as they may contain high proportions of fatty acids specific to their preferred food sources. Within-species variation was very small in the food sources, and Principal Component Analysis (PCA) allowed resolution of most species and sample types into distinct clusters. Variation of fatty acid composition was greater within the consumers, with PCA resolving several clusters by collection location within the site and feeding mode of the animals (suspension feeders, grazers and omnivores). We considered the fatty acid profiles (with particular reference to polyunsaturated fatty acids and essential fatty acids) of the consumers in relation to the food sources to determine which organisms played significant roles in the sequestration and cycling of high quality organic material within the estuary.
\end{abstract}

KEY WORDS: Fatty acids · Food web · Biomarker · Salt marsh · Estuary · Trophic ecology • South Africa

\section{INTRODUCTION}

The dynamics of organic carbon transfer among producers and consumers has interested trophic ecologists for several decades (Fry \& Sherr 1984, Canuel \& Cloern 1995, Connolly et al. 2005). This field of research has proven particularly challenging in aquatic environments, as organisms of interest are often very small, remote and/or behaviourally complex. Furthermore, many consumers have a high degree of feeding plasticity, as the nature and availability of food can vary considerably both spatially and temporally. The study of estuarine systems in particular introduces additional difficulties, as estuaries are trophically complex and support a large variety of primary producers (Meziane et al. 1997, Kharlamenko et al. 2001, Alfaro et al. 2006). In an attempt to cope with the difficulties associated with complex detritusbased systems, a variety of analytical techniques has been used, each with its own suite of limitations. Two methods that provide a time-integrated view of an organism's assimilated feeding history are the determination of (1) stable isotope ratios and (2) fatty acid profiles (Michener \& Schell 1994, Parrish et al. 2000). Stable isotope ratios in animal tissues are used as tracers to original carbon sources as well as indicators of trophic level (Peterson \& Fry 1987), and fatty acids provide information on the type and quality of resources assimilated by animals over ecologically meaningful time periods (Dalsgaard et al. 2003). The most successful biomarkers are those that are unique to a food source in a specific environment and are 
transferred without modification into higher trophic levels (Dalsgaard et al. 2003). When used together, fatty acid and stable isotope techniques show promise in resolving the trophic ecology of complex aquatic ecosystems (Kharlamenko et al. 2001, Alfaro et al. 2006, Perga et al. 2006).

Consumers derive all their lipid requirements either directly from the diet or indirectly by the transformation of protein and carbohydrate precursors. Lipids, particularly the polyunsaturated fatty acid (PUFA) components, have vital structural and functional roles in membranes and are therefore required for growth and reproduction (Arts 1999). Fatty acids that are required for the proper biological functioning of organs, but cannot be effectively synthesized de novo by animals (the essential fatty acids, EFAs), include the

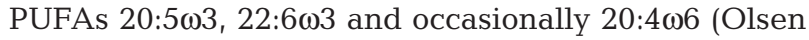
1999). These fatty acids must therefore be obtained in the diet, and, as such, EFAs are highly conserved in aquatic systems and are fundamental drivers of ecosystem fitness and stability (Arts et al. 2001). Trophic ecologists are interested in the sources of PUFAs, and EFAs in particular, and in the consumers that most effectively sequester these molecules within an aquatic ecosystem (Parrish et al. 2000). Most research into fatty acid composition has been focussed on marine fish and shellfish owing to the importance of marine fisheries to human health and nutrition (Arts et al. 2001), but marine and freshwater invertebrates have received increased attention in recent years (Graeve et al. 1997, Goedkoop et al. 2000). Although estuaries represent vital links between freshwater and marine systems and serve as nursery grounds for many commercially important fish, relatively little is known about the fatty acid composition of producers and consumers in estuarine systems throughout the world.

The focal point of our study is a temperate estuary located on the southeastern coast of South Africa. This semi-arid region has low annual rainfall and high rates of evaporation, and most estuaries receive relatively small amounts of freshwater input throughout the year (Davies \& Day 1998). This natural deficiency in riverine water is further augmented by numerous artificial dams in many of the estuaries (Grange et al. 2000). As freshwater inflow is an important source of inorganic nutrients, South African systems are therefore predominantly nutrient limited (Grange \& Allanson 1995). Although inorganic nutrient concentrations in estuaries along the western coast of the country can potentially be replenished by the cold and nutrient-rich Benguela Current seawater during a tidal cycle, the warm oligotrophic Aghulas Current offers minimal nutrient enrichment to eastern coast systems (Grange \& Allanson 1995). Together, these environmental con- straints undoubtedly influence all levels of the food web, and we expect that these limitations will be reflected in the fatty acid compositions (particularly the EFAs) of organisms on the eastern coast of South Africa.

The aims of the current study were 4 -fold: (1) to provide fatty acid composition data on estuarine food sources and consumers for the first time in a South African estuary, (2) to determine whether different groupings of food sources contain unique fatty acids that can be used as trophic markers, (3) to assess the degree of plasticity or omnivory in the diets of the predominant zooplankton, macrofauna and fish in a highly oligotrophic environment, and (4) to compare and contrast the conclusions drawn from fatty acid profiles with previously collected stable isotope ratio data in the same system.

\section{MATERIALS AND METHODS}

Study area. The Kariega Estuary is a permanently open, warm temperate system on the southeastern coast of South Africa $\left(33.6^{\circ} \mathrm{S}, 26.6^{\circ} \mathrm{E}\right)$. A detailed description of the estuary (including physical and biological characteristics of the aquatic environment) is provided in Richoux \& Froneman (2007). Several impoundments along the estuary result in a marinedominated, shallow, stable, oligotrophic and wellmixed microtidal system (Grange \& Allanson 1995). Although physical factors can vary seasonally, the over-riding stability of the system appears to limit any seasonal effects on the food webs (Froneman 2001, Richoux \& Froneman 2007). The intertidal banks along most of the length of the estuary $(18 \mathrm{~km})$ are inhabited by bands of the seagrass Zostera capensis, bare mud or sand, the cordgrass Spartina maritima and the salt marsh plants Sarcocornia perennis and Chenolea diffusa (Hodgson 1987). Several large salt marshes in the middle and lower reaches occupy $\sim 24 \%$ of the surface area of the estuary (Taylor 1987). The sampling site was located adjacent to one of these large salt marshes in the middle reaches, $\sim 5 \mathrm{~km}$ from the estuary mouth. Tidal water enters and leaves the salt marsh through a narrow tidal creek having sediments colonized by few macrophytes (primarily benthic algal mats, Fig. 1). The salt marsh, densely populated with $S$. perennis and C. diffusa, lies at a higher elevation than the tidal creek and covers a relatively large area.

Sample collection and preparation. Water, sediment, plant and animal samples were collected in August and November 2006 ( $\mathrm{N}=1$ to 6 per sample type). Aliquots $(500 \mathrm{ml})$ of estuarine water collected from the channel were homogenized and filtered onto pre-ignited $\left(450^{\circ} \mathrm{C}\right.$ overnight) and pre-weighed GF/F 


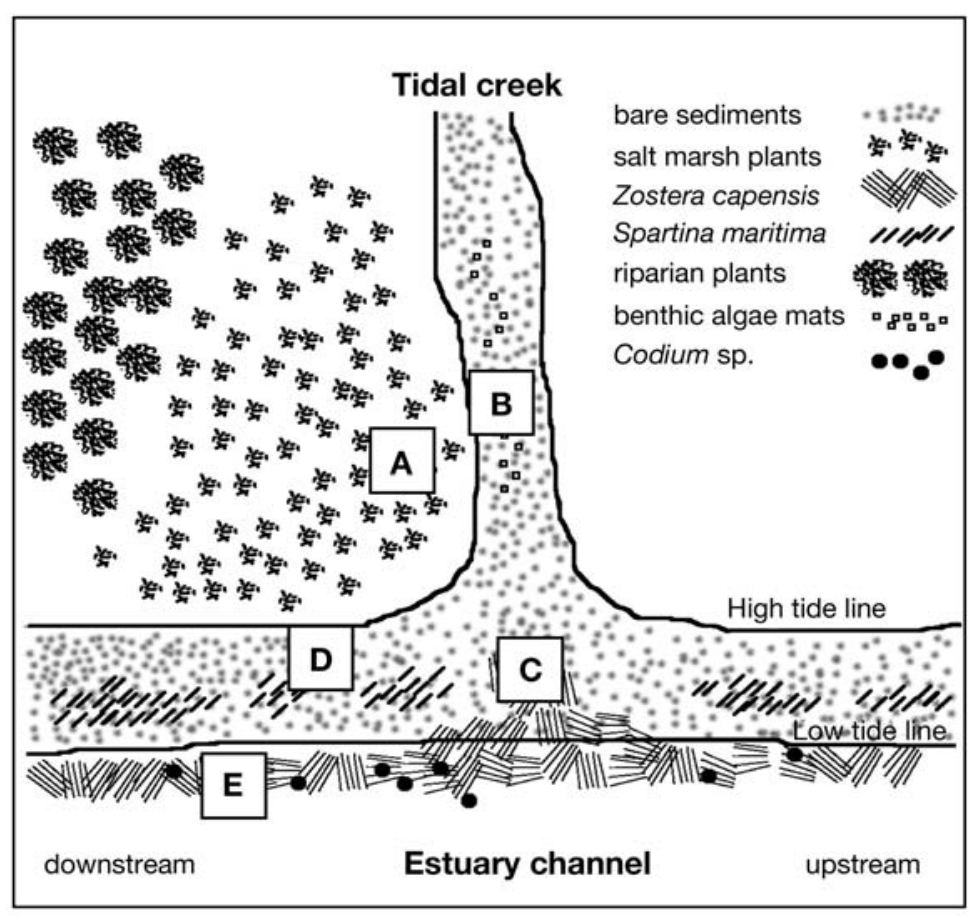

Fig. 1. Areas of sample collection (A-E) in the Kariega Estuary

insulated cooler. Benthic macrofauna were collected by hand in different regions of the site (Fig. 1). For each species collected, animals within a small size range were chosen to restrict any variation with developmental status. The crabs Sesarma catenata (males analyzed separately from gravid females), S. eulimene and Cyclograpsus punctatus were found in the salt marsh area near the tidal creek (Area A), the crabs Cleistostoma edwardsii were found near or within the tidal creek (Areas A and B), specimens of the whelk Nassarius kraussianus and the opisthobranchs Haminoea alfredensis were removed from $Z$. capensis blades at the mouth of the tidal creek (Area C), and individuals of the nereid polychaete Perinereis nuntia vallata were sorted from sediments collected in Area D immediately downstream from the salt marsh inlet. A prawn pump was used to extract mud prawns Upogebia africana from the sediments between Areas D and E. The shrimp Palaemon peringueyi was collected with a hand net in Area E, and

Whatman glass fibre filters $(25 \mathrm{~mm}$ filters; $<5 \mathrm{~cm} \mathrm{Hg}$ vacuum filtration). Zooplankton samples were collected from the channel using a WP-2 net (mouth area $0.25 \mathrm{~m}^{2}, 100 \mu \mathrm{m}$ mesh size, closed cod end) during the night when vertically migrating species concentrate near the surface. Zooplankton were kept alive and aerated at constant temperature for 1 to $2 \mathrm{~d}$ throughout sorting and processing. Several hundred copepods (Pseudodiaptomus hessei and Acartia longipatella) and numerous small mysids were pooled by filtration onto GF/C filters to obtain an adequate signal. The concentration of organisms in several samples was still insufficient to yield reliable analytical results (the technique usually requires $>20 \mathrm{mg}$ of dry mass per sample, depending on the lipid content of the organisms); therefore, an additional sample comprising thousands of individuals was processed as 'mixed zooplankton'. The microzooplankton $(<200 \mu \mathrm{m})$ fraction of the zooplankton community, which can constitute up to $43 \%$ of the seston in the Kariega Estuary, is dominated by ciliates and dinoflagellates (Froneman \& McQuaid 1997), whereas the larger zooplankton fraction $(>200 \mu \mathrm{m})$ is dominated by copepods of the genera Pseudodiaptomus and Acartia (Froneman 2002).

Vegetation (Zostera capensis, Z. capensis epibionts, Sarcocornia perennis, Chenolea diffusa, Spartina maritima, Codium sp., benthic algal mats and assorted dried riparian leaves from the tidal wrack) and surface sediments were collected with a scalpel during the day at low tide and stored in Ziploc ${ }^{\circledR}$ plastic bags inside an klipfishes Clinus superciliosis, gobies Caffragobius gilcristi and C. nudiceps, and specimens of the crab Hymenosoma orbiculare were captured in Area E using a $5 \mathrm{~m}$ seine net. All animals were kept in freshlycollected estuarine water for transport and storage, and macrofauna and fish were allowed to defecate overnight before they were processed further. All samples were rinsed with GF/F filtered seawater. Three types of seagrass preparations were made: (1) 'dirty' $Z$. capensis: seagrass blades and epibionts included, (2) 'clean' Z. capensis: seagrass blades with epibionts removed by scraping with a scalpel and (3) epibionts (seagrass epibionts only). Plants and seston were treated with boiling distilled water $(10 \mathrm{ml}$ were poured over filtered samples, whereas macroflora samples were boiled for $2 \mathrm{~min}$ ) to deactivate lipolytic enzymes (Budge \& Parrish 1999). Animals were lyophilized for $24 \mathrm{~h}$ and homogenized using a mortar and pestle. Dried and weighed animal subsamples [up to $300 \mathrm{mg}$ dry mass (DM)] and wet plant and sediment samples were placed in $2 \mathrm{ml}$ chloroform under nitrogen in lipidcleaned vials and stored at $-20^{\circ} \mathrm{C}$. Total lipids were extracted from each sample using a modified Folch procedure (Parrish 1999) within $4 \mathrm{wk}$ of collection. Samples were ground in 2:1 (v/v) chloroform/ methanol, $0.5 \mathrm{ml}$ of chloroform-extracted water added, and the lipid layers removed and combined following each of 3 chloroform washes. A known quantity of internal standard (19:0) was added to each animal extract to permit fatty acid methyl ester (FAME) quan- 
tification. FAMEs were prepared by heating the extracts suspended in hexane at $80^{\circ} \mathrm{C}$ for $1.5 \mathrm{~h}$ in the presence of $14 \%$ boron trifloride-methanol (method adapted from Budge \& Parrish 1998).

Gas chromatographic (GC) analyses of FAMEs suspended in hexane were performed with a Hewlett Packard 5890A GC equipped with a bonded and crosslinked $78 \%$ cyanopropyl methylpolysiloxane fused silica capillary column (30 m length, $0.25 \mathrm{~mm}$ i.d., $0.25 \mu \mathrm{m}$ film thickness, Quadrex Corporation) with helium as the carrier gas. Aliquots $(1 \mu \mathrm{l})$ of sample were manually injected at $250^{\circ} \mathrm{C}$ with the oven set at $100^{\circ} \mathrm{C}$. After $3 \mathrm{~min}$, the oven temperature was raised to $150^{\circ} \mathrm{C}$ at $5^{\circ} \mathrm{C} \mathrm{min}^{-1}$, held for $1 \mathrm{~min}$, and raised to $220^{\circ} \mathrm{C}$ at $3.5^{\circ} \mathrm{C} \mathrm{min}^{-1}$. The temperature of the flame ionization detector was set at $260^{\circ} \mathrm{C}$. Peaks were integrated using 32Karat 5.0 software (Beckman Coulter) and identified using mass spectral data derived from a subset of the samples and by comparing retention times with those of known external standards (37 component FAMEs standard and marine PUFA no. 1, Supelco). Each fatty acid was reported as a proportion of the total identified fatty acids (\% TFA) and quantitatively as $\mu \mathrm{g}$ fatty acid $\mathrm{mg}^{-1}$ dry mass (animals).

Fatty acids are reported in the shorthand form $\mathrm{x}: \mathrm{a} \omega \mathrm{b}$, where $\mathrm{x}$ is the number of carbon atoms in the acyl chain, a is the total number of double bonds, and b is the position of the first double bond from the methyl end of the molecule. Bacterial fatty acids (BAFAs) refer to those that have odd-numbered carbon chains and/or iso- (i-) and anteiso- (ai-) branches, and higher plant

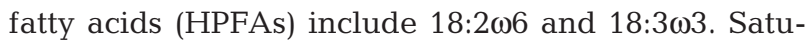
rated fatty acids (SFAs) are those without any double bonds (e.g. 14:0), monounsaturated fatty acids (MUFAs) contain 1 double bond (e.g. 16:107) and polyunsaturated fatty acids (PUFAs) have $>1$ double

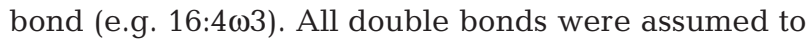
be methylene-interrupted and in cis configuration.

Statistical analysis. Principal Components Analysis (PCA) of proportional and quantitative data was used to examine associations among the food sources and consumers based on their basic fatty acid compositions. To account for problems associated with compositional data, proportional data were log-ratio transformed using a slightly modified equation from Seaborn et al. (2005): $x_{\text {trans }}=\ln \left(\left(x_{i}+1\right) / c_{i}\right)$, where $x_{\text {trans }}$ is the transformed fatty acid, $x_{i}$ is the weight percentage of a given fatty acid and $C_{i}$ is the weight percentage of a reference fatty acid (18:0). The term $x_{i}+1$ was used to account for any zero values in the data sets. Hierarchical cluster analysis (Euclidean algorithm) was performed on the scores to create the groupings indicated in the scores plots. Statistical analyses were completed using PAST 1.42 (Hammer et al. 2001). Variance is reported as one $\mathrm{SD}$.

\section{RESULTS}

\section{Food sources}

Twenty-seven fatty acids were detected at concentrations $>1 \%$ TFA in at least one of the food sources (Table 1). All of the food sources contained large proportions (21 to $37 \%$ TFA) of the SFA 16:0, the major end product of the most common lipid pathway involving Type I fatty acid synthetase (Dalsgaard et al. 2003).

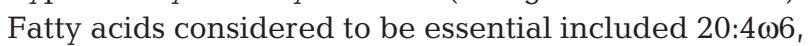
$20: 5 \omega 3$ and $22: 6 \omega 3$. The fatty acids $18: 2 \omega 6$ and 18:3 $\omega 3$ are considered additional EFA in some studies as many carnivorous animals have little or no ability to elongate and desaturate these shorter C18 fatty acids (Olsen 1999, Perga et al. 2006), but they were not treated as EFAs in this study.

Major fatty acids detected in the seston include 16:0, $16: 1 \omega 7,18: 1 \omega 7,20: 3 \omega 6,18: 0,18: 3 \omega 3,20: 5 \omega 3$ and 20:1 $\omega 9$ (Table 1). Bacterial fatty acid (BAFA) and higher plant fatty acid (HPFA) levels were moderate at $4.6 \%$ TFA and $8.8 \%$ TFA, respectively, whereas proportions of EFAs (7.7\% TFA) were among the highest found in all food sources. Seston was dominated by

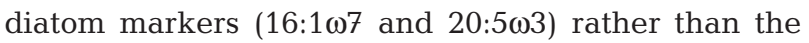
dinoflagellate marker (22:6 $\omega 3)$. PUFA levels were generally low (31\% TFA) relative to fresh specimens of higher plants (61 to $70 \%$ TFA).

The sediments contained the greatest proportions of BAFAs (14.2\%TFA) and elevated proportions of the

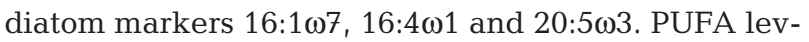
els were markedly low relative to MUFAs and SFAs, indicating that degradation processes were dominant (Derieux et al. 1998), although EFAs were elevated at $8 \%$ TFA owing to the high occurrence of 20:5 03 . HPFA levels were lower than in all other food sources (1.5\% TFA, Table 1).

The profile of 'clean' Zostera capensis was markedly different from its epibionts, in particular because of differences in 14:0,16:1 $17,18: 1 \omega 7,18: 2 \omega 6,18: 3 \omega 3$ and 20:5 13 (Table 1). BAFA, MUFA, SFA and EFA proportions were highest in the epibionts, whereas PUFAs were more prevalent in seagrass leaves (61\% TFA) due to high levels of HPFAs. As in the sediments, low PUFA levels (15\% TFA) relative to MUFA (36\% TFA) and SFA (49\% TFA) indicated the prevalence of decomposition processes in the epibionts as the degree of unsaturation of PUFAs decreases with the degradation of organic material (Derieux et al. 1998).

Moderate amounts of EFAs and HPFAs were detected in the mats of benthic algae (4.3\% and 19\% TFA, respectively), although the profile of this producer was somewhat unique owing to high levels of SFAs and BAFAs (51\% and 10\% TFA, respectively) (Table 1). As in the sediments and epibionts, low proportions of 


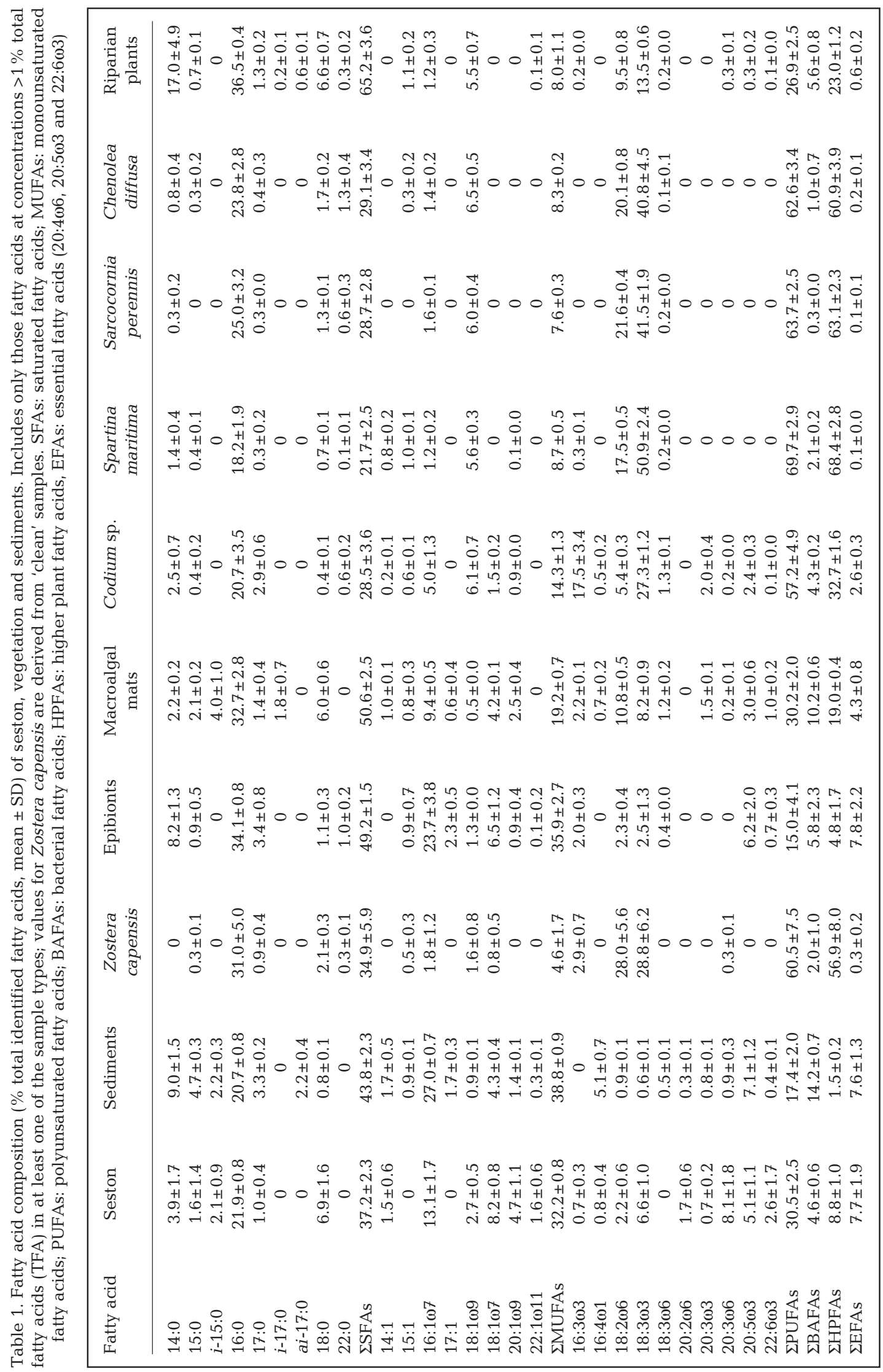


PUFAs relative to SFAs (but not MUFAs) indicated the predominance of microbial processes in the algal mats.

The macroalga Codium sp., characterized by low levels of EFAs and moderate levels of HPFAs, differed from all other food sources by containing elevated amounts of $16: 3 \omega 3$ (18\% TFA). Levels of 18:1 109 were also elevated at $6 \% \mathrm{TFA}$, similar to those found in the salt marsh and riparian plants. Moderate amounts of BAFAs (4.3\%TFA) and elevated amounts of PUFAs (57\% TFA) relative to SFAs (29\%TFA) and MUFAs (14\%TFA) both indicate that the material was relatively fresh and not highly colonized by bacteria.

The fatty acid profile of the cordgrass Spartina maritima was similar to those of the salt marsh plants Sarcocornia perennis and Chenolea diffusa, the primary difference being slightly higher levels of BAFAs, PUFAs and HPFAs in S. maritima (Table 1). All 3 plant species contained elevated levels of 18:1 19 ( 6\% TFA) in addition to large proportions of HPFAs (61 to $68 \%$ TFA). EFA proportions were extremely low in all 3 species ( 0.1 to $0.2 \%$ TFA), whereas PUFA levels were high (63 to $70 \%$ TFA) and indicated minimal microbial degradation.

The decaying riparian vegetation contained elevated proportions of SFAs (65\% TFA) and moderate levels of HPFAs (23\%TFA; Table 1). HPFA levels were undoubtedly greater in fresh samples of the riparian vegetation, and the moderate HPFA levels in the decayed samples indicates the highly refractory nature of these fatty acids even when subjected to intense microbial degradation. Moderate BAFAs (6\% TFA) and decreased PUFAs (27\% TFA) relative to SFAs indicate the dominance of microbial colonization on the riparian plants, which may contribute to the slightly increased EFA levels relative to the salt marsh plants.
Principal components (PC) 1 and 2 resulting from PCA of the food sources explained 77 and $14 \%$, respectively, of the variance in the data set. Hierarchical cluster analysis of PC-1 and PC-2 scores identified 9 groupings (Fig. 2). The salt marsh plants Chenolea diffusa and Sarcocornia perennis were not distinguishable and remained in one cluster, and 'dirty' Zostera capensis samples were not distinguishable from the epibionts, whereas all other food sources had unique profiles that allowed their classification into separate clusters (Fig. 2). Most notable is the complete separation of 'clean' Z. capensis from the epibionts. PC2 separated the higher plants and Codium sp. (all with high

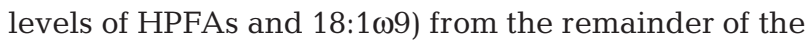
food sources (seston, algal mats, epibionts and sediments) with elevated levels of EFAs and markers for bacteria and diatoms (particularly 16:1 $107,18: 1 \omega 7$ and 20:5 03 ). The third principal component did not provide additional information, therefore PC-3 plots were not included.

\section{Consumers}

Twenty-five fatty acids were detected at concentrations $>1 \%$ TFA in at least one of the consumers (Tables 2 \& 3). Mean data and PCA results are provided for both the proportional and absolute fatty acid contents, as they represent alternative perspectives and result in different association patterns. Quantitative fatty acid content and weight percentages can be used as complementary assessment criteria in trophic ecology (Olsen 1999). Quantitative measures of specific fatty acids are particularly valuable when deter-

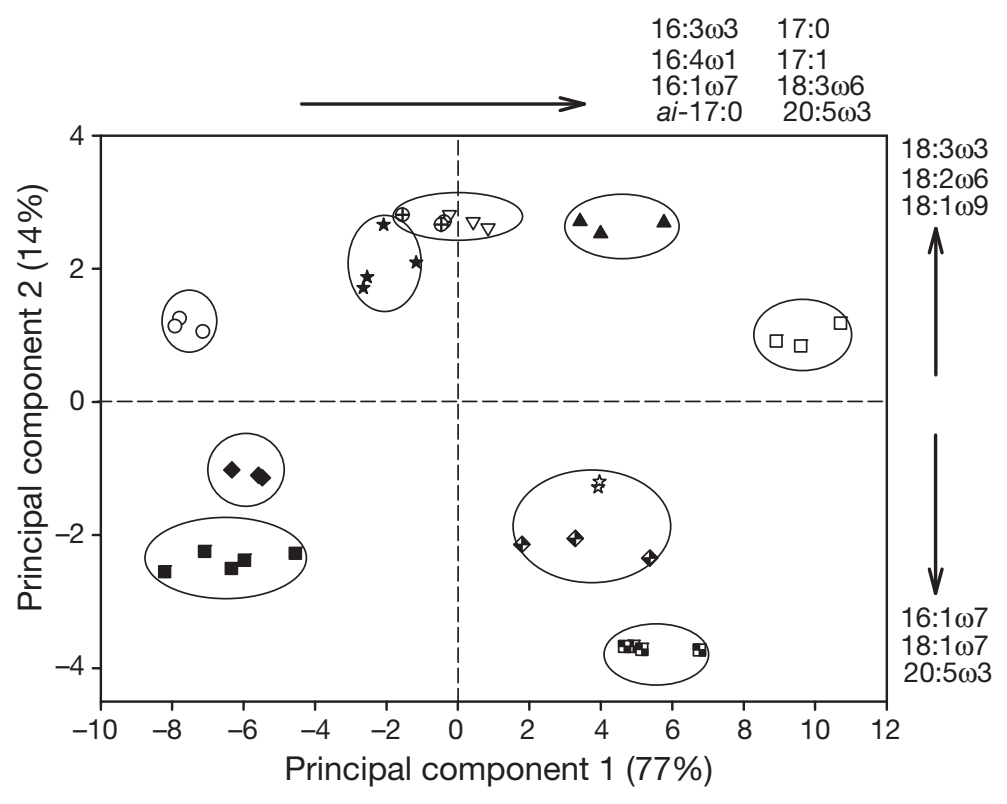

O riparian plants

- benthic algae

- seston

* Zostera capensis clean

$\nabla$ Sarcocornia perennis

$\oplus$ Chenolea diffusa
- Spartina maritima

- Codium sp.

\# Z. capensis dirty

- epibionts

a sediments

Fig. 2. PCA ordination of food sources in the Kariega Estuary. Arrows running parallel to each axis denote the influence of the specified fatty acids, i.e. having loading values $> \pm 0.2$, and ellipses denote the groupings separated by hierarchical cluster analysis 


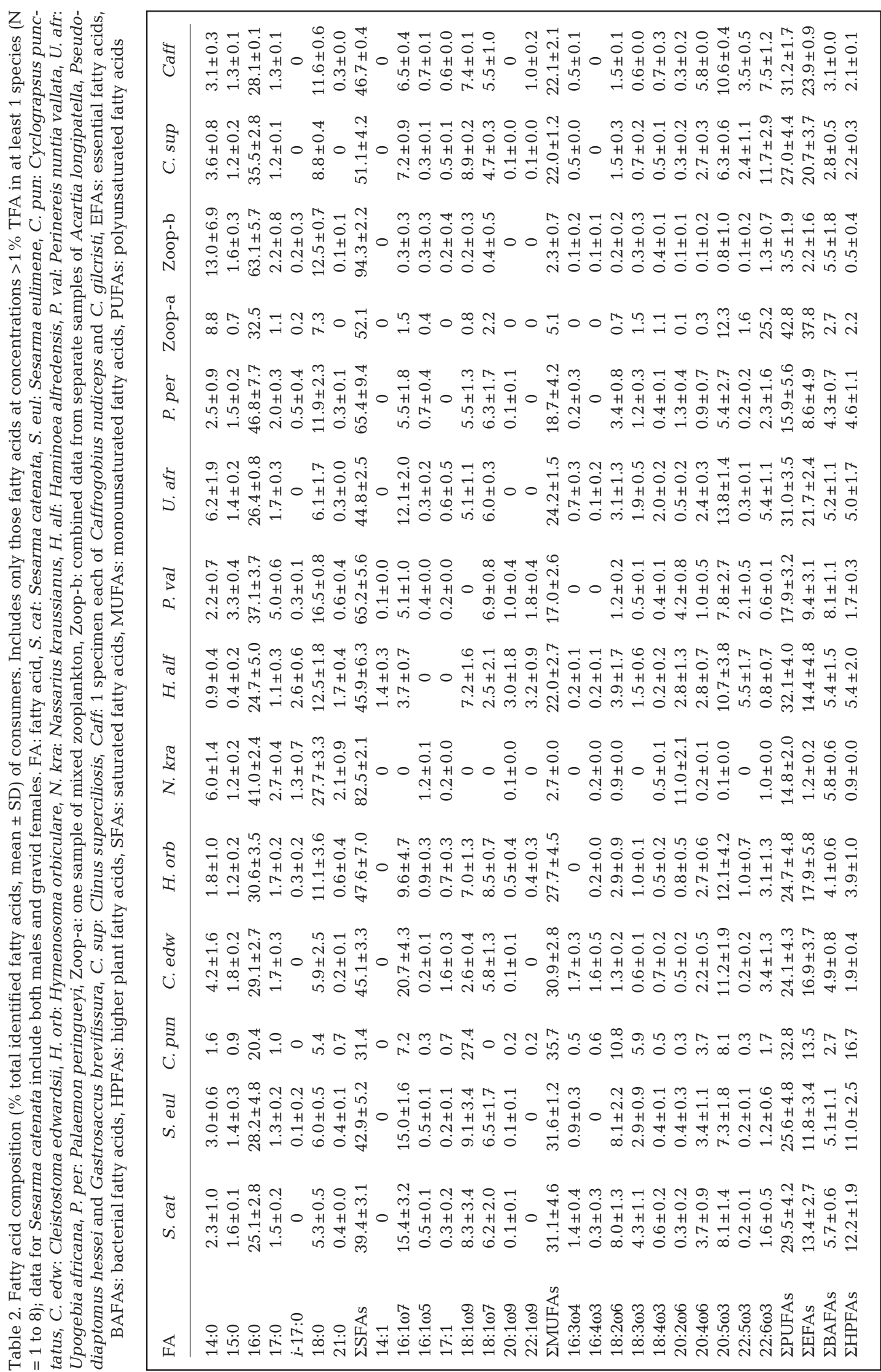




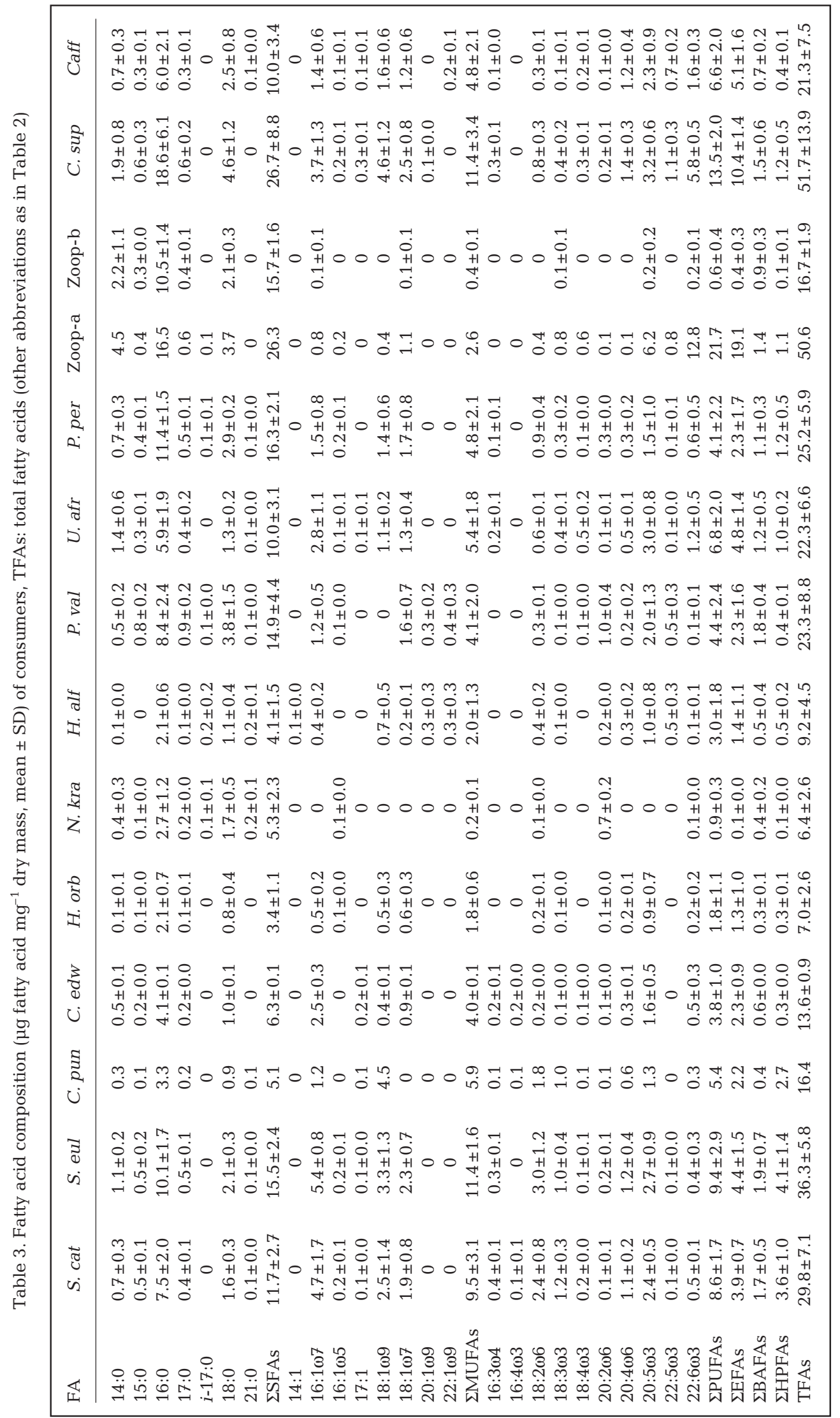


mining nutritional requirements of a species, whereas proportional data are important as different EFAs tend to compete with one another in enzymatic reactions. In this regard, proportional data and biomarker ratios may be more important than their absolute contents (Olsen 1999).

Fatty acid profiles of the crabs Sesarma catenata (data from males and gravid females were similar and therefore combined) and $S$. eulimene were very similar to one another (Tables $2 \& 3$ ) and characterized by moderate levels of diatom markers (16:1 $1 \omega 7$ and 20:5 $\omega 3$ ) and elevated levels of 18:1 $\omega 9$, HPFAs, BAFAs, PUFAs and EFAs. Proportions of the EFA 20:4 16 were highest among these crabs (in addition to the crab Cyclograpsus punctatus); this a fatty acid that was found in only trace amounts within most of the food sources. The sesarmid crabs are thought to feed by scavenging or by removing organic material from mud particles (Branch et al. 1994). Among all the invertebrates, the sesarmids had the greatest absolute amounts of TFA (30 to $\left.36 \mu \mathrm{g} \mathrm{mg}^{-1} \mathrm{DM}\right)$, EFA $\left(\sim 4 \mu \mathrm{g} \mathrm{mg}{ }^{-1} \mathrm{DM}\right)$ and PUFAs ( 9 $\mu \mathrm{g} \mathrm{mg}^{-1} \mathrm{DM}$, Table 3$)$. Individuals of both sesarmid species were collected among the salt marsh plants within Area A and they were grouped together in both PCAs (Figs. $3 \& 4$ ).

The crabs Cleistostoma edwardsii and Cyclograpsus punctatus, also collected from the salt marsh/tidal creek area of the site, were in neighboring clusters in the PCAs (Figs. 3 \& 4). Like the sesarmid crabs, these species had moderate to elevated levels of EFAs and PUFAs, although their TFA contents (14 to $16 \mu \mathrm{g} \mathrm{mg}^{-1}$ DM) were approximately half those of the sesarmids (30 to $36 \mu \mathrm{g} \mathrm{m}^{-1} \mathrm{DM}$, Table 3). C. punctatus, a shore crab thought to scavenge by night on drift seaweeds and animal matter, was characterized by particularly high levels of MUFAs (especially 18:1 $\omega 9$ ) and HPFAs, whereas C. edwardsii, thought to be a detritivore (Branch et al. 1994), contained high levels of diatom

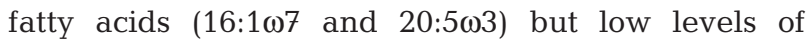
HPFAs.

The 2 gastropods Nassarius kraussianus and Haminoea alfredensis were clustered with the crown crab Hymenosoma orbiculare in the quantitative PCA in accordance with their common association with the seagrass blades (Fig. 3), whereas their alternative dietary habits differentiated them in the percent weight ordination (Fig. 4). N. kraussianus is thought to be a consumer of small bivalves or a general scavenger, whereas $H$. alfredensis grazes on benthic filamentous algae or diatoms (Branch et al. 1994). The profile of $N$. kraussianus was dominated by SFAs, primarily 18:0, whereas $H$. alfredensis had elevated levels of MUFAs, PUFAs and EFAs (Table 2). Like the 2 gastropods, $H$. orbiculare was collected from seagrass beds in Area E, although it is thought to feed on small crustaceans (Branch et al. 1994). Like C. edwardsii, $H$. orbiculare had correspondingly low levels of HPFAs compared with the crabs that were more closely associated with the salt marsh. Although $H$. orbiculare contained very low absolute TFAs $(7 \mu \mathrm{g}$ $\mathrm{mg}^{-1} \mathrm{DM}$ ), the proportions of PUFAs and EFAs were similar to those found in the other crab species (Tables $2 \& 3$ ).

The mud prawn Upogebia africana and the nereid polychaete Perinereis nuntia vallata were grouped together in the quantitative PCA on the basis of their common infaunal habitat (Fig. 3), whereas the percent weight ordination separated them based on their differing dietary habits (Fig. 4). In this latter case, the mud prawns formed a separate cluster adjacent to the other suspension-feeders, whereas the nereids were clustered with omnivores and generalist feeders.

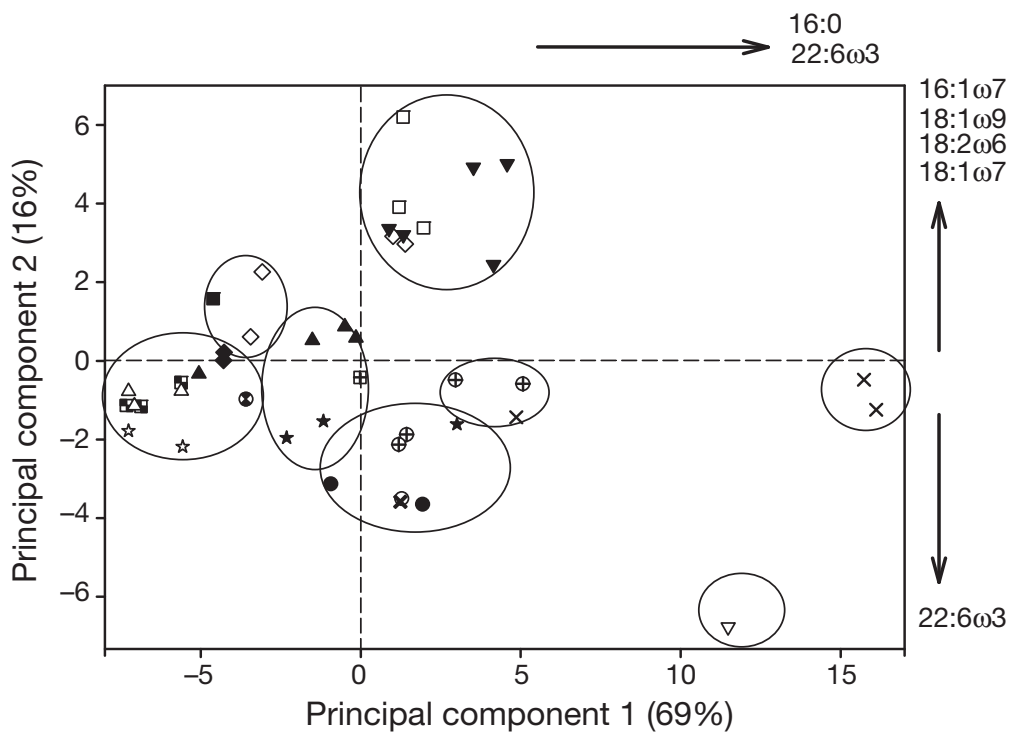

Benthos:

$\diamond$ Sesarma catenata

- Sesarma catenata gf

v Sesarma eulimene

- Cyclograpsus punctatus

- Cleistostoma edwardsii

- Nassarius kraussianus

- Haminoea alfredensis

$\triangle$ Hymenosoma orbiculare

$\star$ Perinereis nuntia vallata

- Upogebia africana
Zooplankton/Nekton:

$\oplus$ Palaemon peringueyi

- Pseudodiaptomus hessei

- Gastrosaccus brevifissura

$\times$ Acartia longipatella

$\nabla$ mixed zooplankton

$\times$ Clinus superciliosis

- Caffrogobius gilcristi

$\rightarrow$ Caffrogobius nudiceps

Fig. 3. PCA ordination of quantitative data on consumers collected in the Kariega Estuary. Arrows running parallel to each axis denote the influence of the specified fatty acids, i.e. having loading values $> \pm 0.2$ 


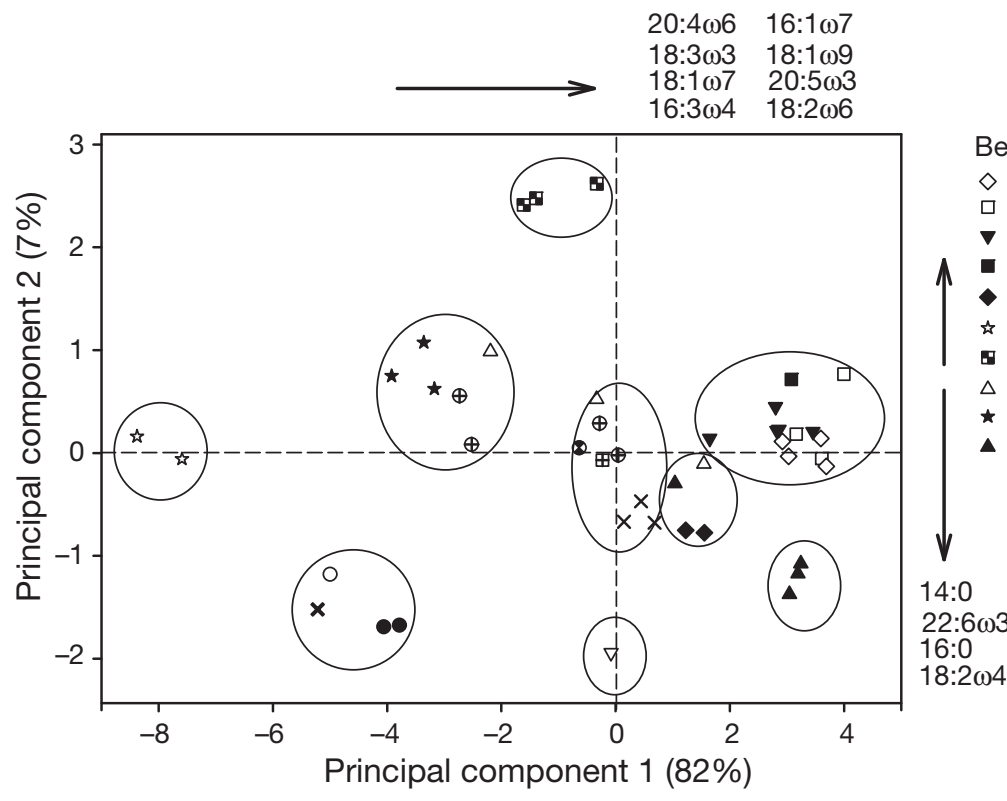

Benthos:

$\diamond$ Sesarma catenata

- Sesarma catenata gf

- Sesarma eulimene

- Cyclograpsus punctatus

- Cleistostoma edwardsii

* Nassarius kraussianus

- Haminoea alfredensis

$\triangle$ Hymenosoma orbiculare

* Perinereis nuntia vallata

- Upogebia africana
Zooplankton/Nekton:

$\oplus$ Palaemon peringueyi

- Pseudodiaptomus hessei

- Gastrosaccus brevifissura

× Acartia longipatella

$\nabla$ mixed zooplankton

$\times$ Clinus superciliosis

- Caffrogobius gilcristi

ד Caffrogobius nudiceps
Absolute TFAs were moderate in both species ( 23 $\mu \mathrm{g} \mathrm{mg}^{-1} \mathrm{DM}$, Table 3), with moderate to high levels of BAFAs (particularly in the nereid polychaete). Of the 2 infauna, the mud prawn contained higher proportions of both PUFAs and EFAs, primarily owing to low 20:5 23 . HPFA levels were low in both species.

Among the pelagic consumers, the sand shrimp Palaemon peringueyi clustered with the generalist omnivores in the percent weight ordination (Fig. 4), but between the channel-based zooplankton/nekton and the benthic invertebrates in the quantitative ordination (Fig. 3). Both groupings confirmed the hyperbenthic/semi-pelagic habitat of the shrimp, as well as an opportunistic scavenging mode of food acquisition. $P$. peringueyi contained moderate quantities of TFAs (25 $\left.\mu \mathrm{g} \mathrm{mg}^{-1} \mathrm{DM}\right)$, which were dominated by SFAs (Tables 2 \& 3). The copepods Acartia longipatella and Pseudodiaptomus hessei and the small mysid Gastrosaccus brevifissura clustered together in both PCA plots, whereas the mixed zooplankton sample had a markedly different fatty acid profile that separated it into independent clusters (Figs. 3 \& 4). TFA quantities were very high in the mixed zooplankton sample compared with all other invertebrates (51 $\mathrm{ug} \mathrm{mg}^{-1}$ DM), whereas the TFAs for combined samples of copepods and mysids was markedly less at $17 \mu \mathrm{g} \mathrm{mg}^{-1}$ DM (Table 3). The mixed zooplankton sample contained elevated proportions of PUFAs and EFAs (particularly 22:6 $\omega 3$ ) relative to all other consumers (43 and $38 \%$, respectively), which was not reflected in the combined samples of copepods and mysids that were dominated by SFAs 14:0 and 16:0 (Table 2). The few ichthyofaunal samples analyzed, including the gobies Caffragobius nudiceps and C. gilcristi and the klipfish Clinus superciliosis, formed centralized clusters in both PCA plots (Figs. $3 \& 4$ ). This indicated generally omnivorous feeding modes in all 3 species, although 2 of the quantitative $C$. superciliosis profiles formed a cluster apart from the main group. Clinus superciliosis had the highest quantities of TFAs

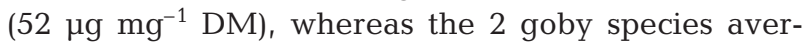
aged only $21 \mu \mathrm{g} \mathrm{mg}^{-1} \mathrm{DM}$ (Table 3 ). All ichthyofaunal samples had elevated levels of both PUFAs (27 to $31 \%$ TFA) and EFAs (21 to $24 \%$ TFA) relative to all other consumers (Table 2).

PC-1 and PC-2 of the quantitative PCA explained $69 \%$ and $16 \%$, respectively, of the variance in the consumer data. Hierarchical cluster analysis of PC-1 and PC-2 scores identified 8 groupings of consumers (Fig. 3), with relatively small within-species variation. Four clusters comprised benthic invertebrates, and pelagic organisms formed the remaining 4 clusters in the lower right quadrant of the PCA scores plot (Fig. 3). The fatty acids with influential loadings on

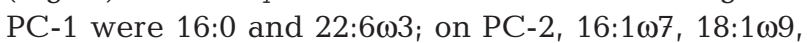
$18: 2 \omega 6,18: 1 \omega 7$ and $22: 6 \omega 3$ had influential loadings (Fig. 3). Each cluster distinguished consumers on the basis of life style and location at the site, with the salt marsh crabs primarily in the top 2 quadrants, the consumers associated with the seagrass beds located at the far left of the plot, the infauna located in the center, and the pelagic organisms in the lower right quadrant (Fig. 3). PC-1 and PC-2 of the percent weight PCA explained $82 \%$ and $7 \%$, respectively, of the variance in the consumer data. Cluster analysis of scores identified 9 groupings of consumers, with numerous fatty acids having influential loadings 
(Fig. 4). Clusters of consumers were distinguished on the basis of feeding mode, with suspension feeders located in the lower 2 quadrants, general omnivores and scavengers located along the center line, and the grazers in the top region of the plot. PC-1 separated the consumers according to diet, with increased influence of HPFAs towards the right side of the plot where the sesarmid crabs clustered (Fig. 4). As with PCA of the food sources, the third principal component did not provide additional information and was not included here.

\section{DISCUSSION}

Our analyses of the food sources and consumers in the oligotrophic Kariega Estuary have revealed some new insights in the region's trophodynamics. Although inorganic nutrient concentrations are low in the Kariega, there are numerous food sources available to a large variety of consumers, thus making trophic tracing particularly challenging. Food sources were readily separated using $\mathrm{PCA}$, although separation of the consumers was not as clear. Despite high variability in fatty acid composition within some of the consumer species, a few of the fatty acids emerged as potential trophic markers. Percent weight PCA indicated that most of the consumers were generalists that differed according to their dominant dietary components, such as salt marsh plant detritus or sediments; the opisthobranch Haminoea alfredensis appeared to be the only true specialist feeder. Furthermore, the PUFA and EFA dynamics among the food sources and consumers provided new information on those species (fish, sesarmid crabs and possibly microzooplankton) that are highly adaptive and successful at sequestering the best quality components from their surroundings. The information discussed herein has helped refine what we have learned from previous work using stable isotope ratios.

\section{Fatty acid biomarkers}

Although PCA distinguished most of the food sources, the distinctions between some groupings were not sufficient for definitive trophic tracing to the consumers. Profiles of all higher plants, apart from the decomposing riparian vegetation, were similar to one another, the seston profiles were similar to those of the benthic algal mats, and the sediments were similar to the seagrass epibionts. Estuarine seston, particularly in an oligotrophic system, contains a high proportion of detritus derived from the decomposition of various primary producers, and we had assumed there would be even more overlap among sources in this detritusdriven environment.

Bacterial production can represent a significant proportion of organic carbon in aquatic food webs, particularly in oligotrophic and detritus-based systems such as the Kariega Estuary (Grange \& Allanson 1995). Although measurement of bacterial production can be a relatively straightforward process (Williams 1984), increased bacterial production is not necessarily reflected at higher trophic levels, and determining the transfer of bacterial carbon within a food chain can be challenging (Kharlamenko et al. 2001). Fatty acid biomarkers have been utilized successfully to assess the bacterial component in a variety of ecosystems and food web types (Ederington et al. 1995, Derieux et al. 1998). The odd carbon-numbered and branched fatty acids, which include 15:0, 17:0 and the iso- and anteiso-branched chain acids, are the most typical bacterial fatty acids (BAFAs) (Volkman et al. 1980, Budge \& Parrish 1998). Among the Kariega food sources, the highest proportions of BAFAs were in the sediments, benthic algal mats, seagrass epibionts and decomposing riparian plants. Elevated proportions of BAFAs also corresponded with low PUFA levels relative to MUFA and SFA in these 4 food sources, particularly in the sediments and epibionts, which further supports the dominance of decompositional processes (Derieux et al. 1998). The values for BAFAs match those of sedimentary organic material in other seagrass communities (Kharlamenko et al. 2001). Similarly, the Kariega consumers had only moderate proportions of BAFAs (3 to $5 \%$ TFA), which correspond to levels in consumers from other seagrass communities (Nichols et al. 1986, Kharlamenko et al. 2001). The infaunal nereid polychaetes contained the greatest proportions of BAFAs $(8 \%$ TFA), indicating deposit-feeding behaviour rather than a more predatory type of food acquisition. The quantitative data also indicated slightly more BAFAs in the sesarmid crabs, which corresponds to feeding on organic material picked from the sediments. Our previous work with stable isotopes was not able to determine the contribution of bacteria to animal diets in the Kariega Estuary (Richoux \& Froneman 2007), as an isotope signature of a sample reflects an average of its components and does not indicate the presence of bacteria per se. Furthermore, in the stable isotope study, the signatures for sediments varied markedly between sites and were often more enriched than the consumers, making it difficult to assess their contribution to animal diets. The $\delta^{13} \mathrm{C}$ signals of the sediments also overlapped with several other food sources including Zostera capensis, epibionts, Spartina maritima and Codium sp., making it impossible to determine whether bacteria associated 
with sediments were trophically important to the consumers (Richoux \& Froneman 2007).

As the principal primary producers in the marine environment, planktonic microalgae are traditionally considered key components in most aquatic trophic studies (Claustre et al. 1989, Cotonnec et al. 2001, Richoux et al. 2005). Markers for marine phytoplank-

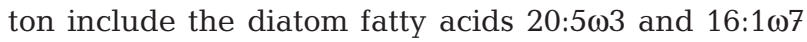
and the dinoflagellate fatty acid 22:6 63 , with high ratios of $16: 1 / 16: 0$ and $22: 6 \omega 3 / 20: 5 \omega 3$ indicating a predominance of diatoms or dinoflagellates, respectively, in the environment and in the diets of consumers (Budge \& Parrish 1998, Dalsgaard et al. 2003). These markers are most useful when diatoms and dinoflagellates are the primary food sources in an ecosystem (Parrish et al. 2000). Multiple sources of dietary carbon were available to consumers in the Kariega Estuary in addition to the phytoplankton component of the seston, therefore the phytoplankton markers played a much reduced role. Furthermore, the microalgal markers were found in smaller proportions within the seston than is typical for aquatic systems (Budge \& Parrish 1998, Kharlamenko et al. 2001, Copeman \& Parrish 2003), likely owing to the low inorganic nutrient levels in the Kariega. Seston PUFAs in most marine systems reach levels of $50 \%$ TFA, with EFA levels up to $40 \%$ TFA (Budge \& Parrish 1998).

In the Kariega Estuary, greatest proportions of the diatom markers 16:1 107 and 20:5 13 were found in sediments and seagrass epibionts rather than seston, indicating the dominance of benthic diatoms rather than planktonic diatoms in the food web. Elevated levels of a second indicator of benthic diatoms ( $\Sigma \mathrm{C} 16 / \Sigma \mathrm{C} 18$, ratio of $\mathrm{C}_{16}$ to $\mathrm{C}_{18}$ fatty acids; Saliot et al. 1991, Parrish et al. 2000) in the sediments $(\Sigma 16 / \Sigma 18=$ $6.3)$ and epibionts $(\Sigma 16 / \Sigma 18=4.5)$ also indicated a strong representation of diatoms in this ecosystem ( $\Sigma 16 / \Sigma 18$ of remaining food sources ranged from 0.3 to 1.5). This trend was reflected in the consumers, with the benthic invertebrates (particularly the salt marsh crabs that rely on the sediments and epibionts as food sources) containing generally higher quantities of diatom markers. Proportions of the dinoflagellate marker 22:6 $\omega 3$, however, were greatest in the seston. This corresponded to elevated levels of 22:6 $\omega 3$ within the ichthyofauna, zooplankton and suspensionfeeding prawns. The PUFA 18:4 13 , used in previous studies as a marker for dinoflagellates (Graeve et al. 1994), was not a major component in any of the food sources.

Macroalgae and terrestrial producers can be highly influential in coastal regions, but they have received less attention than phytoplankton in biomarker research. Long-chain (>24 carbons) fatty acids are often used as biomarkers for terrestrial plants (Bachok et al. 2003), although detecting these molecules is often not possible owing to temperature limitations on most polar GC columns (Parrish et al. 2000), and longchain fatty acids were not detected in the Kariega samples. Previous research has indicated elevated levels of

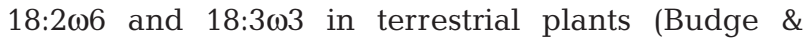
Parrish 1998, Napolitano et al. 1997), and these fatty acids were found in elevated proportions in all the higher plants in the current study. Decreased quantities of these markers were found in the riparian vegetation, probably reflecting the compositional changes induced during decay. For example, Wannigama et al. (1981) found increased levels of bacterial and long chain SFAs in dead mangrove leaves relative to fresh leaves, and a reduction in C18 PUFAs in dead leaves. The MUFA 18:1 19 was also a key component of the higher plants and the macroalga Codium sp. in the Kariega Estuary, although not in the seagrasses; therefore $18: 1 \omega 9$ is an additional potential biomarker for higher plants in this environment. Enhanced quantities of HPFAs and 18:1 $\omega 9$ in the crabs (particularly the sesarmids and Cyclograpsus punctatus) indicated that a significant proportion of their diet comprised salt marsh plants. Seagrasses and Codium sp. were unlikely sources of the HPFAs as the crabs do not inhabit areas of the site occupied by these producers (Fig. 1). Furthermore, the crabs did not obtain HPFAs from sedimentary detritus, which exhibited the lowest HPFA levels in all the food sources. It is therefore most likely that the 3 crab species directly consume the salt marsh plants. Direct consumption of plants by crabs has been documented in several other studies, particularly those focused on mangrove systems (Slim et al. 1997, Hall et al. 2006).

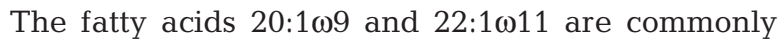
used to indicate consumption of zooplankton. These biomarkers have been used extensively to demonstrate the prevalence of carnivory in marine pelagic food webs and to elucidate specific predator-prey relationships involving calanoid copepods (Saito \& Kotani 2000, Scott et al. 2001). However, 20:1 and 22:1 fatty acids have been of little use as copepod biomarkers in estuarine environments (e.g. Alfaro et al. 2006), and were entirely absent in the copepods and large zooplankton collected in the Kariega Estuary.

\section{Fatty acid composition of food sources}

The fatty acid profiles of seston in the Kariega channel differed from pelagic marine systems (dominated by fatty acids common to diatoms, dinoflagellates and prymnesiophytes, Dalsgaard et al. 2003) and inorganic nutrient-rich estuarine environments characterized by 
seasonal phytoplankton blooms (Canuel 2001). Sediment profiles were more typical of intertidal sediments (Volkman et al. 1980), showing elevated levels of BAFAs and decreased levels of PUFAs. Interestingly, highest levels of EFAs were found in seston, sediments and epibionts, although PUFA levels were extremely low in all 3 food sources. The wide range of fatty acids in all 3 samples indicates contributions of a variety of organic sources. The seston profiles included low levels of phytoplankton, bacterial and higher plant markers in addition to long chain monoenes (20:1 $\omega 9$ and $22: 1 \omega 11)$ that may originate from microzooplankton. In contrast, diatom markers and BAFAs dominated the sediment and epibiont profiles. The benthic algal mats and Codium sp. contained a wide range of fatty acids, the Codium profile resembling those of the higher plants in some aspects (similar levels of 18:3 $\omega 3,18: 1 \omega 9$ and PUFAs) and those of the algal mats in others

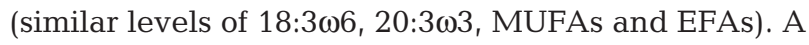
unique and abundant fatty acid in Codium sp., 16:3 133 , identified it a potential biomarker in the food web, although none of the consumers contained significant quantities of this marker.

Apart from the seagrass Zostera capensis, the fatty acid profiles of the higher plants, including Spartina maritima, Sarcocornia perennis and Chenolea diffusa, were virtually indistinguishable from one another and much less complex than the other food sources. Although the salt marsh plants had the highest PUFA quantities of all food sources, none of them contained notable amounts of EFAs. The decomposing riparian leaves contained decreased proportions of HPFAs and PUFAs but slightly elevated levels of EFAs compared with the salt marsh plants, both possible effects of bacterial degradation. Mfilinge et al. (2003) postulated that fatty acid composition can be used to indicate the state of mangrove leaf decay, as microbial activity caused predictable changes in the nutritional quality of leaves over time. Although the SFAs decreased significantly with the decay of leaves, bacterial colonization actually enriched the leaf fragments with PUFAs, thus rendering them more nutritious for consumers (Mfilinge et al. 2003). This is not a consistent finding, as Alfaro et al. (2006) found that PUFA levels were significantly decreased in decomposed mangrove leaves compared with fresh leaves, whereas SFA levels remained constant.

The fatty acid profile of Zostera capensis in the Kar-

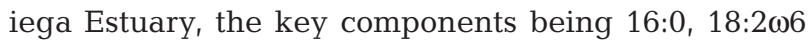
and 18:3 13 , was consistent with Zostera and other seagrass genera studied throughout the world (Nichols et al. 1982, Vaskovsky et al. 1996, Kharlamenko et al. 2001). Most notable were the significant differences in the profiles of the epibionts living on the $Z$. capensis blades (Table 1). The fatty acid profile of epibionts in the current study was remarkably similar to that of Zostera marina epiphytes in the Sea of Japan (Kharlamenko et al. 2001), and Posidonia australis epiphytes in Corner Inlet, Victoria, Australia (Nichols et al. 1985), with all 3 studies indicating a predominance of diatom sources. Markers for seagrasses and epibionts are typically indistinguishable, particularly when using stable isotope ratios (Paterson \& Whitfield 1997, Connolly et al. 2005, Richoux \& Froneman 2007); therefore, the additional use of fatty acid biomarkers increases our ability to measure the contribution of these sources to consumers.

\section{Fatty acid composition of consumers}

The large quantities of HPFAs and 18:109 in the crabs Sesarma catenata, S. eulimene and Cyclograpsus punctatus confirmed that a significant proportion of their diet originated from the higher plants in the Kariega Estuary, namely the cordgrasses and/or salt marsh plants. Enhanced PUFA levels in the higher plants also corresponded with high levels in the sesarmids. The small proportions of 14:0 in these crab species suggested that the decaying riparian vegetation was probably not a significant food

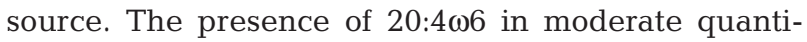
ties in the crabs is interesting, as none of the food sources contained more than traces of this EFA. This

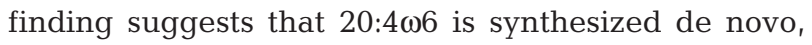
most likely by elongation and desaturation of shorter

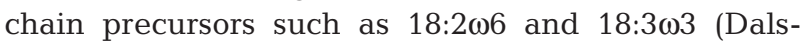
gaard et al. 2003). Alternatively, the crabs may have obtained the EFA from the opportunistic scavenging of allochthonous sources of dead animal material such as fish. Fatty acid profiles partially supported conclusions made from stable isotope signatures, which indicated the presence of $\delta^{13} \mathrm{C}$-enriched sources (in this case Z. capensis or S. maritima) in their diets in addition to seston and possibly benthic algae (Richoux \& Froneman 2007). Fatty acid profiles also indicated a significant contribution of bacteria and diatoms, most likely arising from the sediments rather than the algal mats or seston. In comparison with all other invertebrates, levels of PUFAs and EFAs and absolute quantities of TFAs confirmed that $S$. catenata, S. eulimene and C. punctatus are highly adapted for securing the best quality nutrients available in this environment.

The remaining 2 crab species, Cleistostoma edwardsii and Hymenosoma orbiculare, were less well adapted at sequestering EFAs (as evidenced from lower absolute TFAs), and their fatty acid profiles indicated that they utilized carbon sources different from those of the sesarmid crabs. Unlike the sesarmids, $C$. 
edwardsii and $H$. orbiculare contained high levels of the diatom marker 20:5 $\omega 3$, most likely arising from their increased association with the seagrass epibionts in addition to the benthic diatom-rich sediments. Stable isotope data are not yet available for $\mathrm{H}$. orbiculare, but highly enriched $\delta^{13} \mathrm{C}$ values of $C$. edwardsii relative to the other consumers at the site also support a close dietary dependency of these crabs on the enriched epibionts associated with the seagrass beds (Richoux \& Froneman 2007).

The dominance of the diatom marker 20:5 13 in the opisthobranch Haminoea alfredensis undoubtedly originated from the direct consumption of diatom-rich epibionts. In contrast, the profile of the whelk Nassar-

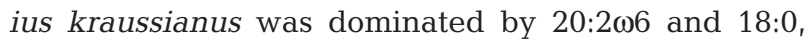
2 fatty acids strongly represented in the seston. How this finding is in accord with the supposed scavenging nature of the whelk is unclear, but low PUFA and EFA levels in addition to low absolute TFAs indicate that this species is not a major component in the transfer of nutrients and energy in the Kariega ecosystem. PUFA and EFA levels in $H$. alfredensis were far higher than those of the whelk, therefore it is better adapted for acquiring high quality lipid components, although TFAs were decreased relative to the other consumers. As in C. edwardsii, highly enriched $\delta^{13} \mathrm{C}$ values of $H$. alfredensis suggested a large contribution of enriched carbon sources (Richoux \& Froneman 2007), although fatty acid profiles definitively eliminated all higher plants as significant dietary sources. Seagrass epibionts therefore emerge as the primary food source for the opisthobranchs, and they are considered the most specialized among the consumers.

Within the 2 infaunal species, the PUFAs, EFAs and

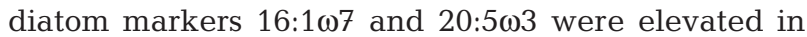
Upogebia africana relative to Perinereis nuntia vallata. As a suspension-feeder, the mud prawn must have obtained these high quality components from the seston and resuspended sediments. $\delta^{13} \mathrm{C}$ signatures of $U$. africana are moderate (range 15 to $20 \%$ ), but are slightly more enriched than other suspension-feeders in the Kariega Estuary (Richoux \& Froneman 2007). The $\delta^{13} \mathrm{C}$ enrichment and the elevated PUFAs and EFAs in $U$. africana relative to suspension-feeding mesozooplankton both indicated higher proportions of resuspended benthic detritus in the mud prawn diet, possibly as a result of its burrowing activities and its close proximity to the sediment surface. $P$. nuntia vallata had enriched $\delta^{13} \mathrm{C}$ signatures relative to other consumers in the Kariega Estuary, indicating the consumption of enriched food sources such as Zostera capensis and Spartina maritima detritus as well as seston and benthic algae, whereas enriched $\delta^{15} \mathrm{~N}$ signatures suggested that animal material may also be an important food source (Richoux \& Froneman 2007).
Minimal quantities of HPFAs showed that the enriched seagrass and cordgrass plants are not important food sources for this species, and elevated BAFA markers indicated that it is probably a detritivore or depositfeeder deriving its nutrition primarily from the sediments. Moderate to high TFA, PUFA and EFA quantities in $U$. africana indicated that it is well adapted to securing high quality organic material from the environment. The nereid polychaete contained low quantities of high quality PUFAs relative to U. africana, but $P$. nuntia vallata could represent an important food item if consumed in great quantities.

As in Perinereis nuntia vallata, moderate to high $\delta^{13} \mathrm{C}$ ratios in Palaemon peringueyi suggested the consumption of a variety of enriched sources, and enriched $\delta^{15} \mathrm{~N}$ signatures suggested that carnivory is important (Richoux \& Froneman 2007). Low quantities of HPFAs in $P$. peringueyi confirmed that Zostera capensis and Spartina maritima are not important food sources, whereas epibionts and microalgae associated with the seagrass and sediments are probably key dietary items and the most likely sources of the diatom biomarkers. PUFA, EFA and TFA quantities were all moderate, so $P$. peringueyi certainly plays a role in the transfer of high quality organic material within the food web.

The suspension-feeding nature and pelagic habitat of the zooplankton were reflected in the fatty acid profiles and the PCA of both proportional and absolute data. The profiles of mixed zooplankton and combined copepods/mysids samples were similar apart from the

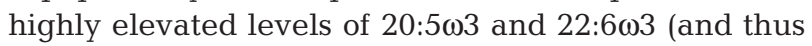
PUFAs, EFAs and TFAs) in the mixed sample, most likely indicating enhanced production of the microzooplankton fraction. Froneman (2002) found that the most effective grazers of phytoplankton in the Kariega channel were the microzooplankton (mainly ciliates and dinoflagellates 20 to $200 \mu \mathrm{m}$ ), whereas the mesozooplankton (copepods) were unable to graze efficiently on the small cells. It follows that the productive picophytoplankton component of the seston community (Froneman 2002) contains the most EFAs, which is in turn reflected in the microzooplankton fraction of the mixed zooplankton sample, as the fatty acid profiles of ciliates tend to reflect their diet (Harvey et al. 1997). Because the 'combined' zooplankton samples contained only mesozooplankton, the low PUFAs, EFAs and TFAs reflected the absence of a highly productive microzooplankton component. The copepods may feed on the motile protozoans in the microzooplankton fraction of the seston, a possible explanation for the elevated levels of BAFAs in the combined zooplankton samples, although no specific protozoan signatures stand out as biomarkers. Further analysis is required to confirm these trophodynamics, as only one mixed zooplankton sample was analyzed. $\delta^{13} \mathrm{C}$ ratios of 
Kariega mesozooplankton were among the most depleted of all the consumers, and they indicated that the phytoplankton and detritus components of the seston were the most important food sources (Richoux \& Froneman 2007). Low levels of HPFAs confirmed that the salt marsh plants, seagrasses and cordgrasses are not significant original sources of carbon for zooplankton, although resuspension of benthic diatoms from sediments and epibionts could certainly contribute to the nutrition of the microzooplankton. Detritus from the benthic algal mats may also serve as an additional original source of nutrition for the larger size fractions of zooplankton.

Additional analysis would be required to confirm the trophic dynamics of the ichthyofauna, but elevated quantities of PUFAs, EFAs and TFAs indicated that these fish are extremely efficient at sequestering and conserving highly nutritive lipid components within the food web. Fatty acid profiles challenge some results from previous research on the ichthyofauna inhabiting the Kariega Estuary, which indicated the presence of a $\delta^{13} \mathrm{C}$-depleted channel community and a $\delta^{13} \mathrm{C}$-enriched littoral community (Paterson \& Whitfield 1997). The klipfish Clinus superciliosis was not one of the species analyzed isotopically, although isotope signatures of the gobies Caffragobius nudiceps and $C$. gilcristi placed them in the enriched littoral group. As such, Paterson \& Whitfield (1997) concluded that the primary food sources for the gobies were highly enriched, namely Spartina maritima, Zostera capensis and its epibionts. In contrast, low levels of HPFAs confirmed that the higher plants were not important original sources of carbon for the ichthyofauna. Furthermore, high levels of the dinoflagellate marker 22:6 13 suggested that the fish were consuming a food source rich in this biomarker, possibly the 22:6 $\omega 3$-enriched microzooplankton, in addition to detritus and invertebrates.

Fatty acid compositions of the food sources and consumers in the Kariega Estuary have shed new light on an extremely complex food web. The profiles have clarifed the role of salt marsh plants and seagrasses as original carbon sources for invertebrates and ichthyofauna, and they have confirmed that the ecosystem is dominated by generalist omnivores, some having an enhanced capacity for sequestering high quality lipid components from the environment.

Acknowledgements. We thank P. Vorwerk, M. Jennings, T. Booth, G. Tweddle and J. Lukey for their support in the field, B. Wilhelmi and R. Tandlich for their assistance in the GC laboratory, and M. Bowker at the Environmental Biotechnology Research Unit for assistance with GC-MS analysis. Funding was provided by the Joint Research Council, Rhodes University and the National Research Foundation of South Africa.

\section{LITERATURE CITED}

Alfaro AC, Thomas F, Sergent L, Duxbury M (2006) Identification of trophic interactions within an estuarine food web (northern New Zealand) using fatty acid biomarkers and stable isotopes. Estuar Coast Shelf Sci 70:271-286

Arts MT (1999) Lipids in freshwater zooplankton: selected ecological and physiological aspects. In: Arts MT, Wainman BC (eds) Lipids in freshwater ecosystems. Springer, New York, p 71-90

Arts MT, Ackman RG, Holub BJ (2001) 'Essential fatty acids' in aquatic ecosystems: a crucial link between diet and human health and evolution. Can J Fish Aquat Sci 58:122-137

Bachok Z, Mfilinge PL, Tsuchiya M (2003) The diet of the mud clam Geloina coaxans (Mollusca, Bivalvia) as indicated by fatty acid markers in a subtropical mangrove forest of Okinawa, Japan. J Exp Mar Biol Ecol 292:187-197

Branch GM, Griffiths CL, Branch ML, Beckley LE (1994) Two oceans: a guide to the marine life of southern Africa. David Phillip, Cape Town

Budge SM, Parrish CC (1998) Lipid biogeochemistry of plankton, settling matter and sediments in Trinity Bay, Newfoundland. II. Fatty acids. Org Geochem 29:1547-1559

Budge SM, Parrish CC (1999) Lipid class and fatty acid composition of Pseudo-nitzschia multiseries and Pseudonitzschia pungens and effects of lipolytic enzyme deactivation. Phytochem 52:561-566

Canuel EA (2001) Relations between river flow, primary production and fatty acid composition of particulate organic matter in San Francisco and Chesapeake Bays: a multivariate approach. Org Geochem 32:563-583

Canuel EA, Cloern JE (1995) Molecular and isotopic tracers used to examine sources of organic matter and its incorporation into the food webs of San Francisco Bay. Limnol Oceanogr 40:67-81

Claustre H, Marty JC, Cassiani L, Dagaut J (1989) Fatty acid dynamics in phytoplankton and microzooplankton communities during a spring bloom in the coastal Ligurian Sea: ecological implications. Mar Microb Food Webs 3: $51-66$

Connolly RM, Gorman D, Guest MA (2005) Movement of carbon among estuarine habitats and its assimilation by invertebrates. Oecologia 144:684-691

Copeman LA, Parrish CC (2003) Marine lipids in a cold coastal ecosystem: Gilbert Bay, Labrador. Mar Biol 143:1213-1227

Cotonnec G, Brunet C, Sautour B, Thoumelin G (2001) Nutritive value and selection of food particles by copepods during a spring bloom of Phaeocystis sp. in the English Channel, as determined by pigment and fatty acid analyses. J Plankton Res 23:693-703

Dalsgaard J, St. John M, Kattner G, Müller-Navarra D, Hagen W (2003) Fatty acid trophic markers in the pelagic marine environment. Adv Mar Biol 46:225-340

Davies BR, Day JA (1998) Vanishing waters. University of Cape Town Press, Cape Town

Derieux S, Fillaux J, Saliot A (1998) Lipid class and fatty acid distributions in particulate and dissolved fractions in the north Adriatic Sea. Org Geochem 29:1609-1621

Ederington MC, McManus GB, Harvey H (1995) Trophic transfer of fatty acids, sterols, and a triterpenoid alcohol between bacteria, a ciliate, and the copepod Acartia tonsa. Limnol Oceanogr 40:860-867

Froneman PW (2001) Seasonal changes in zooplankton biomass and grazing in a temperate estuary, South Africa. Estuar Coast Shelf Sci 52:543-553 
Froneman PW (2002) Trophic cascading in an oligotrophic temperate estuary, South Africa. J Plankton Res 24: 807-816

Froneman PW, McQuaid CD (1997) Preliminary investigation of the ecological role of microzooplankton in the Kariega Estuary, South Africa. Estuar Coast Shelf Sci 45:689-695

Fry B, Sherr EB (1984) Delta ${ }^{13} \mathrm{C}$ measurements as indicators of carbon flow in marine and freshwater ecosystems. Contrib Mar Sci 27:13-47

Goedkoop W, Sonesten L, Ahlgren G, Boberg M (2000) Fatty acids in profundal benthic invertebrates and their major food resources in Lake Erken, Sweden: seasonal variation and trophic indications. Can J Fish Aquat Sci 57: $2267-2279$

Graeve M, Kattner G, Hagen W (1994) Diet-induced changes in the fatty acid composition of Arctic herbivorous copepods: experimental evidence of trophic markers. J Exp Mar Biol Ecol 182:97-110

Graeve M, Kattner G, Piepenburg D (1997) Lipids in Arctic benthos: does the fatty acid and alcohol composition reflect feeding and trophic interactions. Polar Biol 18:53-61

Grange N, Allanson BR (1995) The influence of freshwater inflow on the nature, amount and distribution of seston in estuaries of the Eastern Cape, South Africa. Estuar Coast Shelf Sci 40:403-420

Grange N, Whitfield AK, DeVilliers CJ, Allanson BR (2000) The response of two South African east coast estuaries to altered river flow regimes. Aquat Conserv Mar Freshw Ecosyst 10:155-177

Hall D, Lee SY, Meziane T (2006) Fatty acids as trophic tracers in an experimental estuarine food chain: tracer transfer. J Exp Mar Biol Ecol 336:42-53

Hammer Ø, Harper DAT, Ryan PD (2001) PAST: palaeontological statistics software package for education and data analysis. Palaeontologia Electronica 4, p 9. Available at: palaeo-electronica.org/2001_1/past/issue1_01.htm

Harvey HR, Ederington MC, McManus GB (1997) Lipid composition of the marine ciliates Pleuronema sp. and Fabrea salina: shifts in response to changes in diet. J Eukaryot Microbiol 44:189-193

Hodgson AN (1987) Distribution and abundance of the macrobenthic fauna of the Kariega Estuary. S Afr J Zool 22:153-162

Kharlamenko VI, Kiyashko SI, Imbs AB, Vyshkvartzev DI (2001) Identification of food sources of invertebrates from the seagrass Zostera marina community using carbon and sulfur stable isotope ratio and fatty acid analyses. Mar Ecol Prog Ser 220:103-117

Meziane T, Bodineau L, Retiere C, Thoumelin G (1997) The use of lipid markers to define sources of organic matter in sediment and food web of the intertidal salt-marsh-flat ecosystem of Mont-Saint-Michel Bay, France. J Sea Res 38:47-58

Mfilinge PL, Meziane T, Bachok Z, Tsuchiya M (2003) Fatty acids in decomposing mangrove leaves: microbial activity, decay and nutritional quality. Mar Ecol Prog Ser 265: 97-105

Michener RH, Schell DM (1994) Stable isotope ratios as tracers in marine aquatic food webs. In: Lajtha $\mathrm{K}$, Michener $\mathrm{RH}$ (eds) Stable isotopes in ecology and environmental science. Blackwell Scientific, Oxford, p 138-158

Napolitano GE, Pollero RJ, Gayoso AM, Macdonald BA, Thompson RJ (1997) Fatty acids as trophic markers of phytoplankton blooms in the Bahia Blanca estuary (Buenos Aires, Argentina) and in Trinity Bay (Newfoundland, Canada). Biochem Syst Ecol 25:739-755

Nichols PD, Klumpp DW, Johns RB (1982) Lipid components of the seagrasses Posidonia australis and Heterozostera tasmanica as indicators of carbon source. Phytochem 21:1613-1621

Nichols PD, Klumpp DW, Johns RB (1985) Lipid components of the epiphyte material, suspended particulate matter and cultured bacteria from a seagrass, Posidonia australis, community as indicators of carbon source. Comp Biochem Physiol 80B:315-325

Nichols PD, Klumpp DW, Johns RB (1986) Lipid components and utilization in consumers of a seagrass community: an indication of carbon source. Comp Biochem Physiol 83B:103-113

Olsen Y (1999) Lipids and essential fatty acids in aquatic food webs: what can freshwater ecologists learn from mariculture? In: Arts MT, Wainman BC (eds) Lipids in freshwater ecosystems. Springer, New York, p 161-202

Parrish CC (1999) Determination of total lipid, lipid classes, and fatty acids in aquatic samples. In: Arts MT, Wainman BC (eds) Lipids in freshwater ecosystems. Springer, New York, p 4-20

Parrish CC, Abrajano TA, Budge SM, Helleur RJ, Hudson ED, Pulchan K, Ramos C (2000) Lipid and phenolic biomarkers in marine ecosystems: analysis and applications. In: Wangersky PJ (ed) The handbook of environmental chemistry, Vol 5, Part D. Springer, Berlin, p 193-223

Paterson AW, Whitfield AK (1997) A stable carbon isotope study of the food-web in a freshwater-deprived South African estuary, with particular emphasis on the ichthyofauna. Estuar Coast Shelf Sci 45:705-715

Perga ME, Kainz M, Matthews B, Mazumder A (2006) Carbon pathways to zooplankton: insights from the combined use of stable isotope and fatty acid biomarkers. Freshw Biol 51:2041-2051

Peterson BJ, Fry B (1987) Stable isotopes in ecosystem studies. Annu Rev Ecol Syst 18:293-320

Richoux NB, Froneman PW (2007) Assessment of spatial variation in carbon utilization by benthic and pelagic invertebrates in a temperate South African estuary using stable isotope signatures. Estuar Coast Shelf Sci 71:545-558

Richoux NB, Deibel D, Thompson RJ, Parrish CC (2005) Seasonal and developmental variation in the fatty acid composition of Mysis mixta (Mysidacea) and Acanthostepheia malmgreni (Amphipoda) from the hyperbenthos of a coldocean environment (Conception Bay, Newfoundland). J Plankton Res 27:719-733

Saito H, Kotani Y (2000) Lipids of four boreal species of calanoid copepods: origin of monoene fats of marine animals at higher trophic levels in the grazing food chain in the subarctic ocean ecosystem. Mar Chem 71:69-82

Saliot A, Laureillard J, Scribe P, Sicre MA (1991) Evolutionary trends in the lipid biomarker approach for investigating the biogeochemistry of organic matter in the marine environment. Mar Chem 36:233-248

Scott CL, Falk-Petersen S, Gulliksen B, Lønne OJ, Sargent JR (2001) Lipid indicators of the diet of the sympagic amphipod Gammarus wilkitzkii in the Marginal Ice Zone and in open waters of Svalbard (Arctic). Polar Biol 24:572-576

Seaborn GT, Moore KM, Balazs GH (2005) Depot fatty acid composition in immature green turtles (Chelonia mydas) residing at two near-shore foraging areas in the Hawaiian Islands. Comp Biochem Physiol B 140:183-195

Slim FJ, Hemminga MA, Ochieng C, Jannink NT, Cocheret de la Morinière $E$, van der Velde G (1997) Leaf litter removal by the snail Terebralia palustris (Linnaeus) and sesarmid crabs in an East African mangrove (Gazi Bay, Kenya). J Exp Mar Biol Ecol 215:35-48

Taylor DI (1987) Tidal exchange of carbon, nitrogen and 
phosphorus between a Sarcocornia salt-marsh and the Kariega Estuary, and the role of salt-marsh Brachyura in this transfer. PhD dissertation, Rhodes University, Grahamstown

Vaskovsky VE, Khotimchenko SV, Xia B, Hefang L (1996) Polar lipids and fatty acids of some marine macrophytes from the Yellow Sea. Phytochem 42:1347-1356

Volkman JK, Johns RB, Gillan FT, Perry GJ, Bavor HJ (1980) Microbial lipids of an intertidal sediment I. Fatty acids and

Editorial responsibility: Robert Feller,

Columbia, South Carolina, USA hydrocarbons. Geochim Cosmochim Acta 44:1133-1143

Wannigama GP, Volkman JK, Gillan FT, Nichols PD, Johns RB (1981) A comparison of lipid components of the fresh and dead leaves and pneumatophores of the mangrove Avicennia marina. Phytochem 20:659-666

Williams PJleB (1984) Bacterial production in the marine food chain: the Emperor's new suit of clothes. In: Fasham MJR (ed) Flows of energy and materials in marine ecosystems. Plenum Press, New York, p 271-29

Submitted: May 28, 2007; Accepted: November 9, 2007 Proofs received from author(s): March 19, 2008 